\title{
Tindak Tutur Direktif Imam Katolik pada Ritus Pengakuan Dosa dan Penerapan Penitensi oleh Umat Katolik Di Kota Medan
}

\author{
Ermina Waruwu ${ }^{1}$, Emma Martina Pakpahan ${ }^{2}$, Benediktus Benteng Kurniadi ${ }^{3}$ \\ E-mail: ${ }^{1}$ erminawaruwu@ unprimdn.ac.id, ${ }^{2}$ emmathina@gmailcom, ${ }^{3}$ gabrielsing@gmail.com \\ Universitas Prima Indonesia
}

\begin{abstract}
ABSTRAK
Penelitian ini bertujuan mendeskripsikan faktor-faktor minimnya partisipasi umat Katolik untuk mengaku dosa, tindak tutur direktif Imam dan penerapan penitensi umat Katolik. Permasalahan penelitian didasarkan atas wawancara kepada 2 (dua) Imam yang mengtakan bahwa hanya 2,05\% dari 24.444 jiwa umat Katolik yang melakukan pengakuan dosa. Subyek penelitian terdiri atas 12 orang Imam dan 25 orang umat Katolik yang dipilih secara purposive sampling. Teknik pengumpulan data menggunakan googleform berisikan pertanyaan yang dijawab oleh Imam dan umat. Pendekatan teori menggunakan pendekatan pragmatik sedangkan pendekatan penelitian menggunakan kualitatif deskriptif dan analisis data dengan cara mereduksi, menyajikan data serta menarik kesimpulan. Untuk mengukur keabsahan data menggunakan teknik trianggulasi. Hasil penelitian menunjukkan faktor minimnya pengakuan dosa yaitu umat belum memahami pengakuan dosa, dianggap pengakuan dosa tidak terjamin kerahasisaannya, umat malu dan takut mengaku dosa. Tindak tutur direktif Imam kepada umat Katolik terdiri atas tindak tutur bersifat meminta, mengajak, menyarankan, menyuruh dan mengharapkan. Intinya agar umat mengaku dosa kepada Imam. Umat Katolik menerapkan penitensi dalam bentuk doa, derma, karya amal dan pelayanan kepada sesama, pantang secara suka rela dan berkorban. Akhirnya, baik imam dan umat merekomendasikan agar diadakan program katekese tentang pengakuan dosa demi peningkatan partisipasi aktif umat dalam mengaku dosa baik secara kuantitas dan kualitas.
\end{abstract}

Kata Kunci: Tindak Tutur Direktif, Imam Katolik, Penitensi, dan Pengakuan Dosa

\section{PENDAHULUAN}

Tindak tutur dalam komunikasi mencakup tindak konstatif, direktif, komisif, dan persembahan. Tindak tutur berlangsung di setiap peristiwa tutur. Tindak tutur direktif adalah tindak tutur yang dimaksudkan penuturnya (Imam) agar mitra tutur melakukan tindakan sesuai apa yang disebutkan di dalam tuturannya. Indikator dari tuturan direktif adalah adanya suatu tindakan yang dilakukan oleh mitra tutur (peniten) setelah mendengar tuturan tersebut.

Salah satu peristiwa tutur adalah ritus pengakuan dosa yang dilakukan oleh umat Katolik kepada Imam di Gereja. Pengakuan dosa ialah umat katolik mengakukan dosadosanya kepada pelayan yang legitim (Imam tertahbis), menyesali dosa, memperbaiki diri dari perbuatan jahat. Pelayan pengakuan dosa adalah Imam atau Uskup tertahbis yang 
memiliki potestas ordinis (kuasa tahbisan) terhadap umat beriman yang menerima absolusi (pengampunan) dan mendapatkan rekonsiliasi (pendamaian).

Seseorang yang melakukan pengakuan dosa di depan imam disebut Peniten. Penitensi adalah tindakan tobat umat katolik yaitu doa, derma, karya amal, pelayanan terhadap sesama, pantang secara suka rela, dan berkorban. Penitensi disampaikan melalui tindak tutur direktif Imam kepada peniten dalam ritus pengakuan dosa.

Permasalahan penelitian didasarkan wawancara kepada 2 (dua) Imam yang bertugas di salah satu Gereja Katolik St. Yosef Delitua, tanggal 15 dan 22 Maret 2019 yakni umat berjumlah 24.444 Jiwa dan hanya 500 Jiwa atau 2,05 \% umat Katolik yang melakukan pengakuan dosa. Padahal berdasarkan fakta empiris dan biblis bahwa semua orang telah berbuat dosa dan telah kehilangan kemuliaan Allah (Roma, 3:23). Oleh karena itu, idealnya semua orang mengaku dosa demi rekonsiliasi kepada Tuhan, sesama dan alam. Rumusan permasalahan penelitian tersebut ialah 1) Apa saja faktor-faktor penyebab minimnya partisipasi umat Katolik dalam melakukan pengakuan dosa kepada Imam?, 2) Bagaimana tindak tutur direktif Imam kepada Peniten (umat katolik yang mengaku dosa) dalam ritus pengakuan dosa?, 3) Bagaimana penerapan penitensi (tindakan tobat) yang di lakukan oleh Peniten sesudah ritus pengakuan dosa?

Penelitian ini bertujuan 1) untuk menganalisis dan mendeskripsikan faktor-faktor penyebab minimnya partisipasi umat untuk mengaku dosa kepada Imam 2) untuk menganalisis dan mendeskripsikan tindak tutur direktif Imam kepada Peniten (umat katolik yang mengaku dosa) dalam ritus pengakuan dosa, 3) untuk menganalisis dan mendeskripsikan penerapan penitensi (tindakan tobat) yang dilakukan oleh Peniten (umat yang mengaku dosa) sesudah ritus pengakuan dosa.

Hasil yang diharapkan dari penelitian ialah 1) Adanya peningkatan jumlah dan motivasi umat katolik agar berpartisipasi melakukan pengakuan dosa, 2) Agar Imam atau pihak Gereja Katolik kota Medan memberikan pengajaran hakekat pengakuan dosa kepada umat katolik di Medan, 3) agar umat Katolik konsisten menerapkan penitensi (tindakan tobat) secara konkrit.

Penelitian penting/urgen karena 1) Masalah penelitian ini merupakan salah satu hakekat ajaran Gereja Katolik dan tidak pernah diteliti siapapun, 2) Agar umat katolik taat melakukan perintah gereja/agama katolik, 3) Agar umat Katolik menerapkan nilai-nilai religiositas, baik dalam hidup menggereja, bermasyarakat, berbangsa dan bernegara. Oleh karena itu peneliti melakukan penelitian dengan judul "Tindak Tutur Direktif Imam Katolik Pada Ritus Pengakuan Dosa dan Penerapan Penitensi Oleh Umat Katolik Di Kota Medan”.

\section{TINJAUAN PUSTAKA}

Tindak tutur menurut Searle adalah teori yang mencoba mengkaji makna bahasa yang didasari pada hubungan tuturan dengan tindakan yang disampaikan penutur [13]. Istilah tindak tutur pertama kali dimunculkan oleh Austin (1962), di dalam tulisannya How to Do Thing with Words yang menyatakan bahwa kalimat meskipun dapat digunakan untuk memberitakan sesuatu, namun pengujaran kalimat dalam hal tertentu dapat dianggap sebagai 
pelaksanaan tindakan/perbuatan [30]. Tindak tutur dibahas dalam kajian pragmatik yang mengkaji bahasa dari aspek pemakaian aktual. Tindak tutur adalah suatu ujaran sebagai suatu fungsional dalam komunikasi artinya ujaran atau tuturan mengandung maksud [10]. Artinya, pokok kajian utama pragmatik adalah tindak tutur bukan kalimat sebagai satuan dalam gramatika [15].

Menurut John R. Searle (1969) tindak tutur dibedakan atas tiga jenis tindakan, yaitu: tindak lokusi (tindak lokusioner); tindak ilokusi (tindak ilokusioner), dan tindak perlokusi (tindak perlokusioner). Tindak lokusi (lokusioner) adalah tindak untuk menyatakan sesuatu. Tindak tutur tersebut dapat dikatakan sebagai "the act of saying something". Tindak ilokusioner adalah tindak untuk melakukan sesuatu "The act of doing something". Tindak perlokusi merujuk pada efek yang dihasilkan penutur dengan mengatakan sesuatu. Tindak tutur dalam komunikasi mencakup tindak konstatif, direktif, komisif, dan persembahan. Tindak tutur berlangsung di setiap peristiwa tutur [4].

Peristiwa tutur adalah terjadinya/berlangsungnya interaksi linguistik dalam satu bentuk ujaran atau lebih yang melibatkan dua pihak, yaitu penutur dan mitra tutur, dengan satu pokok tuturan, di dalam waktu, tempat, dan situasi tertentu. Peristiwa tutur pada dasarnya merupakan rangkaian dari sejumlah tindak tutur yang terorganisasikan untuk mencapai suatu tujuan. Apabila peristiwa tutur merupakan gejala sosial maka tindak tutur merupakan gejala individual, bersifat psikologis, dan keberlangsungannya ditentukan oleh kemampuan bahasa si penutur dalam menghadapi situasi tertentu. Jika dalam peristiwa tutur lebih dilihat pada tujuan peristiwanya, tetapi dalam tindak tutur lebih dilihat pada makna/arti tindakan dalam tuturannya. Tindak tutur dan peristiwa tutur merupakan dua gejala yang terdapat pada proses komunikasi [2]. Tindak tutur diungkapkan secara lugas sehingga mudah dipahami oleh mitra tutur [12].

Tindak tutur direktif adalah tindak tutur yang dimaksudkan penuturnya agar mitra tutur melakukan tindakan sesuai apa yang disebutkan di dalam tuturannya [11]. Yang termasuk ke dalam tindak tutur direktif ini antara lain tuturan meminta, mengajak, memaksa, menyarankan, mendesak, menyuruh, menagih, memerintah, memohon, menantang, memberi aba-aba. Indikator dari tuturan direktif adalah adanya suatu tindakan yang dilakukan oleh mitra tutur setelah mendengar tuturan tersebut [15].

Salah satu peristiwa tutur adalah pengakuan dosa yang dilakukan oleh umat Katolik. Pengakuan dosa sebagai salah satu perintah Gereja/agama katolik yang dilakukan sekurangkurangnya sekali setahun yaitu masa Prapaska (bulan Maret, sebelum Paskah) dan masa Adven (bulan November sebelum Natal) [8]. Pengakuan dosa melibatkan Imam sebagai penutur dan peniten sebagai mitra tutur. Pada pelaksanaan ritus pengakuan dosa imam menyampaikan tindak tutur kepada umat yang mengaku dosa dihadapannya dengan tujuan agar mitra tutur melakukan tindakan (penitensi) sesuai apa yang disebutkan di dalam tuturan.

Pengakuan dosa ialah umat beriman mengakukan dosa-dosanya kepada pelayan yang legitim (Imam tertahbis), menyesali dosa, berniat memperbaiki diri sehingga melalui absolusi (pengampunan) yang diperoleh melalui Imam dapat diperdamaikan kembali dengan Allah dan anggota Gereja yang mereka lukai dengan berdosa $\left[6^{\mathrm{Kan} .959}\right]$. Pengakuan dosa atau 
penyampaian dosa membebaskan kita dan merintis perdamaian (rekonsiliasi) dengan orang lain $\left[5^{1455}\right]$.

Penyebab manusia berdosa sehingga enggan mengaku dosa, karena manusia bertindak melanggar perintah Allah, mengikuti godaan setan, rusaknya relasi manusia dengan Allah, alam semesta, menyalahkan sesama $\left[7^{\text {Kejadian 3; Roma 5:12 }}\right.$, menentang perintah Tuhan [7 $7^{\text {Ulangan 9:7; Yosua }}$ ${ }^{1: 18}$ ], tidak puas dengan kekuasaan dan kemewahan [ $7^{\text {Yesaya 14:12-15 }}$, kedegilan hati yang licik/hati yang membatu [ $7^{\text {Yeremia, 7:24 }}$, melanggar hukum Allah [ $\left.7^{\text {Yohanes 3:4 }}\right]$. Dosa berakar dalam hati dan menimbulkan berbagai hal lahiriah yang buruk [1] seperti percabulan, pencurian, pembunuhan, perzinaan, keserakahan, kejahatan, meninggalkan Allah [7 $\left.7^{\text {Markus 7:21-23; Lukas 15:11-32 }}\right]$.

Pengakuan dosa dilakukan di depan Imam Katolik sebagai pelayan pengakuan $\left[6^{\text {Kan965-966 }}\right]$ yang telah memiliki kuasa tahbisan (potestas ordinis) untuk memberikan absolusi yang sah. Absolusi adalah sebuah pernyataan pengampunan atau pembebasan atas dosa-dosa pribadi kepada orang yang bertobat yang diberikan oleh Imam [ $\left.7^{\text {Roma 3;9-10 }}\right]$. Imam hanyalah sebagai "pelayan" pengakuan dosa karena hanya Tuhan yang dapat mengampuni dosa $\left[5^{1441}\right]$ : "Dosamu telah diampuni" [ $7^{\text {Markus 2:5; Lukas 7:48 }}$. Oleh karena berkat otoritas Ilahi-Nya (Tuhan), ia memberi kuasa (potestas ordinis) kepada manusia (Imam) supaya dapat dilaksanakan atas nama-Nya (Tuhan). Tuhan, Yesus Kristus mempercayakan pelaksanaan kuasa absolusi kepada jabatan apostolik (Imam) dengan kata lain kepada Imam tertahbis dipercayakan

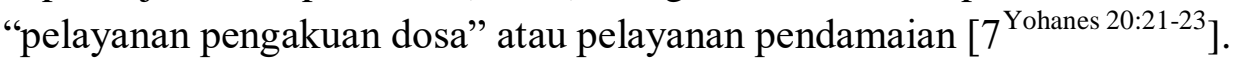

Seseorang yang melakukan pengakuan dosa di depan imam disebut Peniten. Kegiatan Peniten ialah "melakukan penyesalan dalam hati, mengakui perbuatan dosa dengan jujur dan tidak melakukan dosa dalam tindakan" $\left[5^{1450}\right]$. Pengakuan di depan Imam merupakan bagian hakiki sakramen pengakuan dosa $\left[5^{1456}\right]$ : "dalam pengakuan para peniten harus menyampaikan semua dosa berat yang mereka sadari setelah pemeriksaan diri secara seksama...". Dosa adalah satu "perkataan, perbuatan, atau satu keinginan yang bertentangan dengan hukum abadi" [5 $\left.5^{1871-1872}\right]$. Dosa adalah satu tindakan melawan akal budi, melukai kodrat manusia dan mengganggu solidaritas manusia. Dosa yang dilakukan dapat berat apabila dilakukan dengan kesadaran penuh seperti membunuh, berzinah, mencuri, bersaksi dusta, tindak kekerasan terhadap orangtua dan sebagainya $\left[5^{1858}\right]$. Peniten (pendosa) harus mendapat kesehatan rohani yang penuh. Ia harus "membuat silih" untuk dosa-dosanya, harus memperbaiki kesalahan atas suatu cara yang cocok, penyilihan ini dinamakan "Penitensi". Penitensi yang disampaikan bapa Pengakuan (Imam), harus memperhatikan keadaan pribadi peniten dan melayani kepentingan rohaninya. Sejauh mungkin harus sesuai dengan berat dan kodrat dosa yang dilakukannya.

Penitensi (tindakan tobat) terdiri atas doa, derma, puasa, karya amal, pelayanan terhadap sesama, pantang secara suka rela, berkorban dan sebagainya..." [5 $\left.5^{1460}\right]$. Penitensi tersebut disampaikan Imam kepada Peniten (pendosa) pada saat pelaksanaan ritus pengakuan dosa di Gereja atau di tempat-tempat doa $\left[6^{\mathrm{Kan} .964}\right]$. Penitensi tersebut berisikan tindak tutur direktif yang disampaikan oleh Imam kepada mitra tutur (Peniten). Tindak tutur direktif Imam dimaksudkan agar mitra tutur (peniten) melakukan tindakan (penitensi) sesuai dengan apa yang disebutkan di dalam tuturan. Tindak lanjutan dari tutur direktif yang disampaikan oleh Imam ialah penerapan Penitensi (tindakan konkret tobat) yang dilakukan oleh umat sebagai perwujudan nilai-nilai agama dalam kehidupan masyarakat. 


\section{METODE PENELITIAN}

Desain penelitian ini menggunakan pendekatan kualitatif yang bersifat deskriptif. Penelitian ini bersifat deskriptif karena data yang diperoleh tidak dituangkan dalam bentuk bilangan atau angka statistik tetapi peneliti memaparkan gambaran mengenai objek dan hasil kajian dalam bentuk naratif [9]. Pendekatan yang digunakan dalam penelitiaan ini adalah pendekatan pragmatik, yaitu memfokuskan pada bahasa yang digunakan untuk berkomunikasi dalam situasi tertentu. Pendekatan ini dipilih karena yang menjadi objek dalam penelitian ini adalah tindak tutur [11]. Pragmatik berhubungan dengan analisis tentang apa yang dimaksudkan orang dengan tuturan-tuturannya dan maknanya sehingga dapat mempengaruhi tindakan seseorang [14].

Penelitian ini dilaksanakan di gereja-gereja katolik kota Medan dan sekitarnya. Subyek penelitian (informan) dipilih secara purposive sampling artinya peneliti menetapkan subyek penelitian yang benar-benar memahami informasi yang ingin didapatkan. Informan yang ditetapkan dalam penelitian yakni 12 (dua belas) Imam-imam conventual sebagai pelayan pengakuan dosa (penutur), Imam bertugas dan bertempat tinggal di Pastoran gereja katolik di kota Medan dan 25 (dua puluh lima) umat Katolik (peniten) yang telah melakukan pengakuan dosa kepada Imam-imam Conventual.

Sumber data penelitian ini terdiri atas data primer dan data sekunder. Data primer penelitian yakni 1) faktor-faktor penyebab minimnya partisipasi umat untuk mengaku dosa kepada Imam 2) tindak tutur direktif Imam kepada Peniten (umat katolik yang mengaku dosa) dalam ritus pengakuan dosa, 3) penerapan penitensi (tindakan tobat) yang dilakukan oleh Peniten (umat yang mengaku dosa) sesudah ritus pengakuan dosa. Sedangkan data sekunder ialah informasi atau dokumentasi yang berkaitan dengan tindak tutur direktif dan pengakuan dosa. Dengan kata lain sumber data berupa hasil data tentang "Tindak Tutur Direktif Imam Katolik Pada Ritus Pengakuan Dosa dan Penerapan Penitensi Oleh Umat Katolik Di Kota Medan"

Teknik pengumpulan data dalam penelitian menggunakan googleform yang disi secara jujur oleh informan penelitian yaitu diisi oleh Imam-imam Conventual dan umat katolik (peniten) yang memahami dan dapat memberikan informasi sesuai tujuan penelitian.

Untuk melancarkan proses penelitian dan agar tujuan penelitian tercapai maksimal peneliti menyiapkan instrumen berupa pedoman pertanyaan penelitian yang yang berisikan tentang "Tindak Tutur Direktif Imam Katolik Pada Ritus Pengakuan Dosa dan Penerapan Penitensi Oleh Umat Katolik Di Kota Medan”.

Analisis data dilakukan dengan cara melakukan reduksi data, penyajian data dan penarikan kesimpulan. Analisis data dilakukan dengan tahapan-tahapan yaitu 1) Transkripsi data, maksudnya mendeskripsikan data berdasarkan tuturan yang diperoleh melalui googleform, 2) Identifikasi data, maksudnya data yang sudah ada diberi kode sesuai permasalahan penelitian, 3) Klasifikasi data, maksudnya mengklasifikasikan data berdasarkan permasalahan penelitian, 4) Interpretasi data, maksudnya menafsirkan data yang telah diklasifikasikan, 5) Deskripsi data, maksudnya data yang telah diklasifikasi dan diinterpretasi kemudian dirumuskan menjadi sebuah kesimpulan setiap pokok permasalahan. 
Untuk menetapkan keabsahan data diperlukan teknik pemeriksanaan [9], yaitu dengan kriteria-kriteria Trianggulasi; artinya 1) peneliti membandingkan dan mengecek kembali derajat kepercayaan informasi yang diperoleh melalui hasil data (transkrip tindak tutur direktif imam), 2) peneliti melakukan pengecekan derajat kepercayaan sumber data dengan metode yang digunakan 3) peneliti melakukan secara teliti pengecekan hasil data (fakta) dengan berbagai teori 4) peneliti melakukan auditing sehingga menghasilkan hasil penelitian yang kredibel

\section{HASIL PENELITIAN DAN PEMBAHASAN}

Imam-imam Conventual menyatakan bahwa secara kuantitas hanya sebagian kecil saja umat Katolik yang datang mengaku dosa kepada Imam. Apabila adapun hanya pada periode tertentu misalnya pada masa penerimaan Komuni Pertama atau penerimaan Sakramen Ekaristi dan masa Advent atau Praspaskah. Disinyalir umat Katolik mulai kurang berminat mengaku dosa kepada Imam. Imam dari Paroki Santo Yosef, Delitua RP. Pascal Hanoe, OFMConv, menyatakan "De facto, kurang diminati lagi. Amat sedikit orang yang datang ke bilik pengakuan dosa terakhir ini. Jika adapun hanya saat moment prapaskah dan adven. Pada hari-hari biasa, khususnya hari sabtu dan minggu menjelang perayaan Ekaristi jarang yang datang meminta pengakuan dosa". RP. Pascal mengamati bahwa akhir-akhir ini umat katolik mulai tidak tertarik mengaku dosa, apabila adapun hanya pada moment tertentu seperti Prapaskah dan Advent. Kenyataan ini memprihatinkan karena sebenarnya pengakuan dosa tidak hanya pada moment tertentu tetapi pada hari-hari lain atau kapan saja. Sebenarnya, sakramen pengakuan dosa bersifat wajib agar memperoleh pengampunan dosa (absolusi) dan penitensi yang disampaikan oleh Imam kepada umat saat pengakuan dosa. Alasan wajib pelaksanaan pengakuan dosa, pertama; manusia bangkit menuju kehidupan spiritual yakni manusia hidup baru dalam kasih dan martabat manusia diangkat segambar dan secitra dengan Allah sendiri. Hal ini secara tegas dinyatakan RP. Pascal Hanoe, OFMConv, Paroki St. Yosef Delitua: "karena penerimaan pengampunan dosa dari Tuhan melalui sakramen tobat dapat membawa kita pada kebangkitan spritual yakni kita bangkit lagi untuk menerima hidup baru dalam kasih. Pengakuan dosa menjadikan hidup kita yang telah dicemari oleh dosa diangkat kembali kepada martabat hidup yaitu segambar dan secitra dengan Allah sendiri”. Dengan kata lain, apabila sakramen pengakuan dosa tidak dilakukan maka tidak bisa hidup dalam kasih dan tetap tinggal dalam lumpur dosa sehingga seseorang tidak bisa mencerminkan keagungan martabat citra diri Tuhan, Yesus Kristus dalam seluruh hidupnya.

Pengakuan dosa bagi umat dinyatakan sangat bermakna. Salah satu makna yang paling dasariah ialah pendamaian. Pendamaian ini hanya akan terjadi jika umat mau mengakui dosanya kepada Tuhan melalui Imam. RP. Pascal Hanoe, OFMConv mendefenisikan makna pengakuan dosa yaitu 1) pengakuan dosa dapat mendamaikan kita dengan Allah sehingga memperoleh rahmat. Sebab, dosa dapat membuat relasi antara Allah dan manusia menjadi renggang bahkan terputus. 2) Pengakuan dosa dapat mendamaikan hubungan kita dengan Gereja, artinya akibat dosa bukan hanya dapat memutuskan hubungan kita dengan Allah melainkan memutuskan hubungan kita dengan sesama, khususnya warga 
Gereja. 3) Pengakuan dosa dapat membuat kita berdamai kembali dengan semua makhluk dan alam lingkungan.

\section{A. PANDANGAN PARA IMAM TENTANG FAKTOR-FAKTOR PENYEBAB MINIMNYA PARTISIPASI UMAT KATOLIK DALAM PENGAKUAN DOSA}

Secara kuantitas partisipasi aktif umat Katolik untuk mengaku dosa sangat minim. Faktorfaktor minimnya pengakuan dosa ini karena beberapa hal, antara lain: pemahaman umat tentang sakramen pengakuan dosa sangatlah minim. Sulit bagi umat Katolik melakukan apa yang tidak dipahami. Dengan kata lain, umat tidak mengakui dosanya kepada Imam karena tidak memiliki pengetahuan tentang makna dan substansi sakramen pengakuan dosa. Selain itu, umat menganggap bahwa dosa-dosanya tidak terjamin kerahasiaannya. Sebenarnya, hukum Gereja Katolik menjaga rahasia pengakuan dosa yakni dosa-dosa umat sangat dilarang dipublikasikan oleh Imam dalam bentuk apapun. Fakta ini diakui oleh RP. Tri Chandra Fajariyanto, Paroki St. Yosef Delitua bahwa "partisipasi umat yang mengaku dosa sangatlah minim, penyebabnya ialah umat kurang memahami sakramen rekonsiliasi dan umat khawatir jika Imam mengetahui dosa-dosanya". Selain itu, umat malu atau segan menyampaikan dosa-dosanya kepada Imam bahkan dirasakan menakutkan.

Walaupun secara umum banyak umat yang tidak aktif mengaku dosa namun sebagian umat yang telah mengaku dosa kepada Imam telah konsisten melaksanakan penitensi atau tindakan tobat dalam hidup harian. Tindakan tobat yang dilakukan oleh umat antara lain melakukan puasa, terlibat dalam kegiatan liturgi gereja, memberi sedekah di panti asuhan dengan rasa suka cita. RP. Tawar Antoni Ginting, paroki Sang Penebus Bandar Baru menegaskan kenyataan ini: "Secara umum iya, hal ini ditandai dalam bentuk puasa, umat terlibat dalam kegiatan perayaan liturgi dan memberi sedekah di panti asuhan dengan rasa suka cita"

\section{B. TINDAK TUTUR DIREKTIF IMAM KATOLIK DALAM RITUS PENGAKUAN DOSA}

Sebenarnya, para imam telah banyak menyampaikan tuturan yang bersifat direktif bagi umat Katolik terkait pelaksanaan pengakuan dosa. Tuturan-tuturan yang bersifat direktif dari para imam Conventual tersebut dijelaskan berikut ini:

\section{Tuturan direktif bersifat meminta}

Tuturan yang bersifat direktif itu antara lain termaktub dalam tuturan "permintaan" para Imam kepada umat. Para imam meminta agar umat lebih giat melakukan pengakuan dosa karena pengakuan dosa dapat membaharui kehidupan sehingga unsur rohani manusia lebih sehat karena dosa telah diampuni. Para imam juga meminta agar umat lebih sadar akan kerapuhan diri karena cepat tergoda jatuh dalam dosa. Permintaan para Imam ini bertujuan agar tercipta relasi yang harmonis antara manusia dengan Tuhan, sesama dan alam. 


\section{Tuturan direktif bersifat mengajak}

Selain tuturan meminta para Imam menyampaikan tuturan yang bersifat "mengajak" bahkan ajakan ini tidak hanya melalui tuturan namun para imam mengajak dengan cara mendatangi rumah umat. Ajakan para Imam terkait pelaksanaan pengakuan dosa antara lain, "mengaku dosalah kepada Imam" agar bebas dari dosa dan jangan menunggu melakukan dosa berat barulah datang mengakukan dosa. Umat juga diajak mengaku dosa kepada Imam karena manusia kurang memiliki potensi kuat untuk menolak tawaran kejahatan, manusia cepat jatuh atas tawaran kejahatan dosa. Umat juga diajak agar jangan malu dan takut mengaku dosa karena kerahasiaan pengakuan dosa tetap terjaga dan agar umat mempelajari makna dan pelaksanaan praktik tobat daripada memikirkan perasaan malu dan takut.

\section{Tuturan direktif bersifat menyarankan}

Tuturan menyarankan tentang ritus pengakuan dosa juga disampaikan oleh Imam kepada umat Katolik. Ada beberapa isi tuturan yang bersifat saran, antara lain: 1) Umat menyadari terus-menerus bahwa diri tiap orang rentan jatuh dalam kesalahan dan dosa karena itu umat memanfaatkan sarana pengampunan dosa dari gereja yakni aktif melakukan pengakuan dosa sehingga pendamaian antara Allah, sesama dan alam-lingkungan dapat tercipta, 2) Umat berpartisipasi secara aktif dalam pengakuan dosa agar memperoleh berkat Tuhan dalam kehidupan. 3) Umat melakukan pengakuan dosa minimal sekali setahun agar ada perubahan hidup ke arah yang lebih baik. 4) Memperkuat tenaga atau agen pastoral untuk melaksanakan katekese demi meningkatkan pemahaman umat terkait hakekat sakramen pengakuan dosa. 5) Para imam membuat jadwal pelayanan pengakuan dosa harian untuk melayani umat kemudian jadwal itu agar diinformasikan kepada umat.

\section{Tuturan direktif bersifat seruan-menyuruh}

Tuturan direktif juga bersifat menyuruh yang dikemas dengan istilah "seruan" yang disampaikan Imam kepada umat Katolik. Secara ringkas seruan-seruan imam kepada umat Katolik antara lain 1) Agar memahami bahwa sakramen pengakuan dosa (Tobat) adalah sakramen yang ditetapkan oleh Yesus Kristus yang digunakan sebagai sarana untuk menyucikan manusia dari dosa-dosa. 2) Sadar bahwa sakramen pengakuan dosa penting dilakukan agar kehendak Tuhan lebih dapat dimengerti dan umat melaksanakannya dalam hidup harian. 3) Agar umat bersuka cita melakukan pengakuan dosa dan hilangkan rasa malu atau takut mengaku dosa kepada Imam. 4) Agar umat mengikuti katekese-katekese pengakuan dosa sehingga mengerti makna dan substansinya.

\section{Tuturan direktif bersifat mengharapkan}

Berdasarkan tuturan imam yang bersifat direktif di atas akhirnya ada harapan para imam kepada umat katolik agar selalu menyadari perbuatan yang telah dilakukan dan mampu mempertanggungjawabkannya. Selain itu, umat memahami substansi sakramen pengakuan dosa dan menerapkan penitensi atau tindakan tobat dalam kehidupan keluarga, masyarakat 
dan hidup menggereja. Selanjutnya, para Imam berharap agar ada peningkatan pengakuan dosa baik secara kuntitatif maupun kualitatif sehingga hidup beriman umat berkualitas.

Untuk mencapai harapan di atas para imam serentak mengatakan bahwa perlu dan penting melaksanakan katekese tentang pengakuan dosa. Ada dua alasan kepentingan pelaksanaan katekese pengakuan dosa, Pertama: alasan kateketis 1) agar umat tidak lagi malu mengaku dosa dan memahami tata cara dan kerahasiaan seputar pengakuan dosa, 2) agar umat memahami makna sakramen pengakuan dosa dan menerapkan penitensi dalam hidup sehari-hari, 3) agar umat di tempat yang jauh dari pusat paroki ikut serta dalam pengakuan dosa. Kedua: alasan teologis, 1) Pengakuan dosa adalah jalan setiap umat beriman untuk bertobat dan kembali menjadi anak Allah, 2) Pengakuan dosa dapat menjadi pedagogi iman bagi umat Katolik, 3) Pengakuan dosa berfungsi dan berperan untuk menyelamatkan manusia dari dosa sehingga selamat untuk mencapai hidup yang kekal.

\title{
C. PENERAPAN PENITENSI PENGAKUAN DOSA OLEH UMAT KATOLIK DI KOTA MEDAN
}

Secara umum pengakuan dosa yang terakhir yang dilaksanakan oleh umat yakni sejak tahun 2018 sampai tahun 2020. Berdasarkan keterangan ini umat Katolik melaksanakan kewajiban sesuai amanat dalam perintah Gereja Katolik yakni "mengaku dosalah sekurangkurangnya sekali setahun”. Umat Katolik telah melaksanakan pengakuan dosa minimal sekali dalam satu tahun.

\author{
Gambar 1
}

Pengakuan Dosa Terakhir Umat Katolik

\section{Pengakuan Dosa Terakhir Umat Katolik}

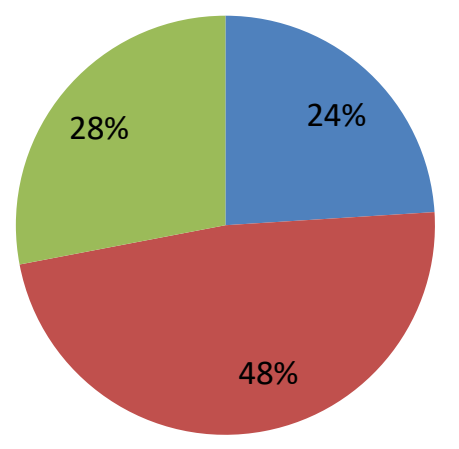

- Pengakuan Dosa 2018

- Pengakuan Dosa 2019

- Pengakuan Dosa 2020 
Ada beberapa alasan wajib dan makna pengakuan dosa yang dinyatakan oleh umat Katolik di kota Medan, Sumatera Utara antara lain: 1) Sakramen pengakuaan dosa adalah Sakramen Rekonsiliasi, Pertama; Rekonsiliasi dengan Allah (Aspek Kristologis) artinya sakramen pengakuan dosa mendamaikan kembali manusia dengan Allah. Berkat daya pendamaian dengan Allah, manusia hidup dalam keadaan berahmat. Kedua; Rekonsiliasi dengan Gereja (Aspek Eklesiologis) artinya, efektivitas rahmat yang mengalir dari Sakramen Rekonsiliasi juga mendamaikan hubungan kaum beriman dengan Gereja. Dosa tidak hanya memutuskan hubungan antara kaum beriman dengan Allah, melainkan juga dengan sesama, terutama dengan seluruh warga Gereja.. Ketiga; Rekonsiliasi dengan semua makhluk dan lingkungan, artinya dari hakikatnya, manusia bersekutu dengan semua makhluk (Roma 8,1922). Semua makhluk dan alam lingkungan mengeluh karena dosa dan keserakahan manusia yang mengeksploitasi semua sumber alam, tanpa memikirkan dampak terburuk bagi lingkungan alam maupun bagi manusia itu sendiri. Saat ini, terasa sulit bagi manusia untuk bernapas segar karena tingginya polusi udara dan asap. Saat ini juga sangat sulit bagi manusia untuk menemukan sumber air yang jernih, bersih, segar dan banyak ikannya karena pembuangan limbah. Alam lingkungan rusak dan menjerit karena keserakahan dan dosa manusia. Karena itu, pertobatan manusia harus juga terarah pada usaha untuk membangun dan melestarikan kembali alam-lingkungan. 2) Sakramen pengakuan dosa adalah sakramen pengampunan dosa manusia. Peniten memperoleh pengampunan dosa karena belas kasihan Allah atas penghinaan yang dilakukan manusia berdosa kepada Allah. Peniten didamaikan dengan anggota Gereja lain yang telah ia dilukai karena dosa. Gereja membantu pertobatan orang berdosa (peniten) dengan cinta kasih, teladan dan doa. 3) Sakramen pengakuan dosa adalah sakramen pertobatan, artinya orang yang mengaku dosa secara sakramental dipanggil oleh Allah untuk bertobat, bangkit dan kembali kepada Allah (Mrk 1:15).

Namun, karena kelemahan kodrat manusiawi membuat manusia condong melakukan dosa (concupiscentia). Oleh karena itu, umat berjuang untuk melawan kencondongan melakukan dosa dan berusaha untuk mencapai hidup kudus dengan cara bertobat melalui pengakuan dosa. 4) Sakramen pengakuan dosa membuat manusia memperoleh ketenangan. Dosa dapat membuat manusia tidak tenang secara psikis. Dosa dapat menaklukkan manusia kepada kebodohan, kesengsaraan dan kekuasaaan serta kematian. Akhirnya manusia kehilangan rahmat dalam dirinya. Hal ini disebabkan karena manusia cenderung melakukan dosa (concupiscentia). Oleh karena itu, orang yang mengakukan dosanya diampuni melalui sakramen pengakuan dosa sehingga memperoleh kedamaian batin dan kedamaian dengan diri sendiri, berdamai dengan saudara-saudara yang dilukai dan juga berdamai dengan seluruh ciptaan. 
Gambar 2

Alasan dan Makna Sakramen Pengakuan Dosa

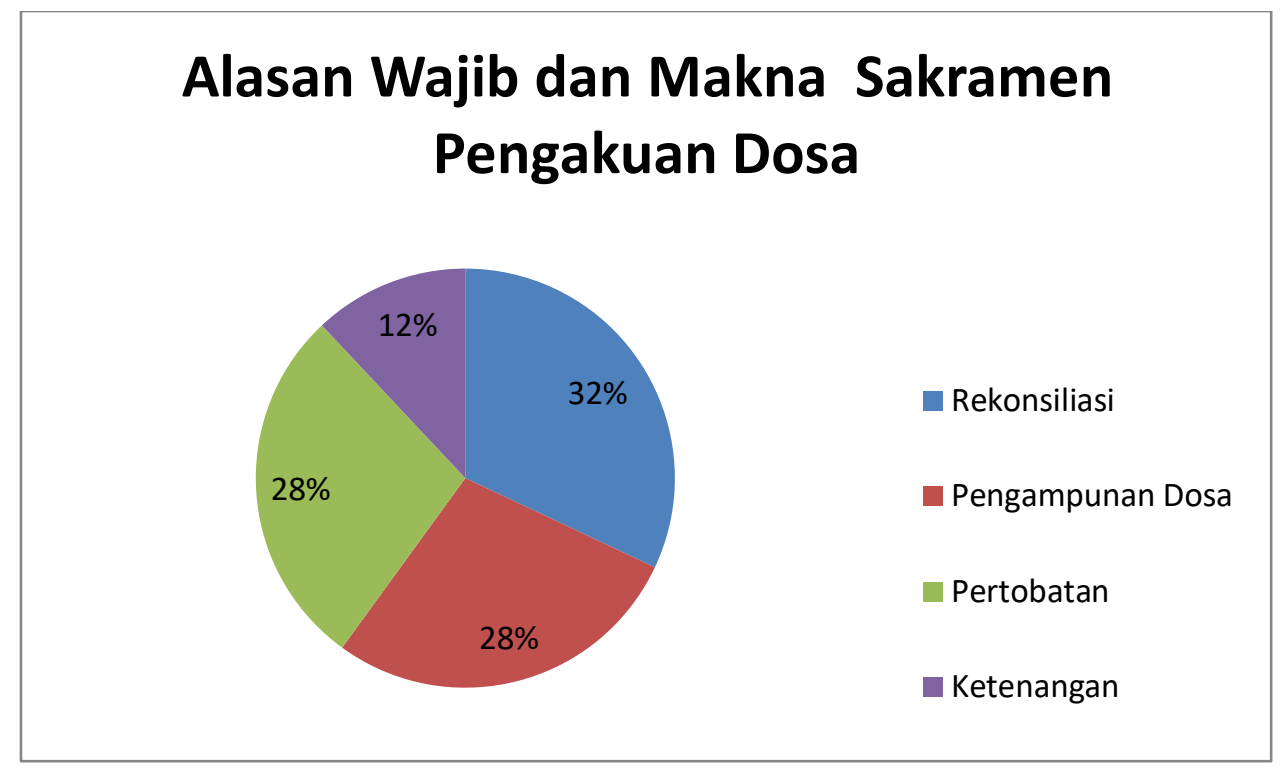

Namun secara umum dan faktual umat Katolik menyampaikan bahwa partisipasi umat untuk mengaku dosa kepada Imam diamati masih minim. Faktor-faktor minimnya umat Katolik melakukan pengakuan dosa disebabkan karena pemahaman umat Katolik tentang ajaran sakramen pengakuan dosa kurang maksimal. Hal ini mengakibatkan umat malu datang kepada Imam untuk mengaku dosa dan malu menyampaikan isi dosa yang sudah dilakukan. Sebenarnya, Imam bertindak sebagai wakil Tuhan untuk memberikan pengampunan dosa kepada peniten. Kuasa pengampunan ini diberikan oleh Tuhan kepada Imam pada saat menerima sakramen Tahbisan. Imam diberi kepercayaan untuk mengenakan kepribadian, tindakan dan teladan Tuhan (in persona Christi) dalam memberikan dan melayani pengakuan dosa peniten. Maka, sebenarnya tidaklah beralasan apabila umat menyatakan takut dan malu untuk mengaku dosa kepada Imam atau takut karena dosa akan dibongkar Imam dihadapan publik. Imam terikat oleh hukum Gereja bahwa dosa-dosa yang disampaikan oleh peniten dilarang membongkar dan menyebarluaskannya untuk kepentingan tertentu. Hukum Gerejawi Katolik ini secara tegas dinyatakan dalam Kitab Hukum Kanonik yang menyatakan sama sekali tidak dibenarkan bahwa bapa pengakuan (Imam) dengan kata-kata atau dengan suatu cara lain serta atas dasar apapun menghinati peniten sekecil apapun. Selain itu, minimnya umat Katolik melakukan pengakuan dosa karena tidak terlaksananya katekese tentang sakramen pengakuan dosa. Katekese ialah penyampaian ajaran kristen yang diberikan secara organis dan sistematis. Ajaran Kristen yang disampaikan ialah inti ajaran tentang sakramen pengakuan dosa. 


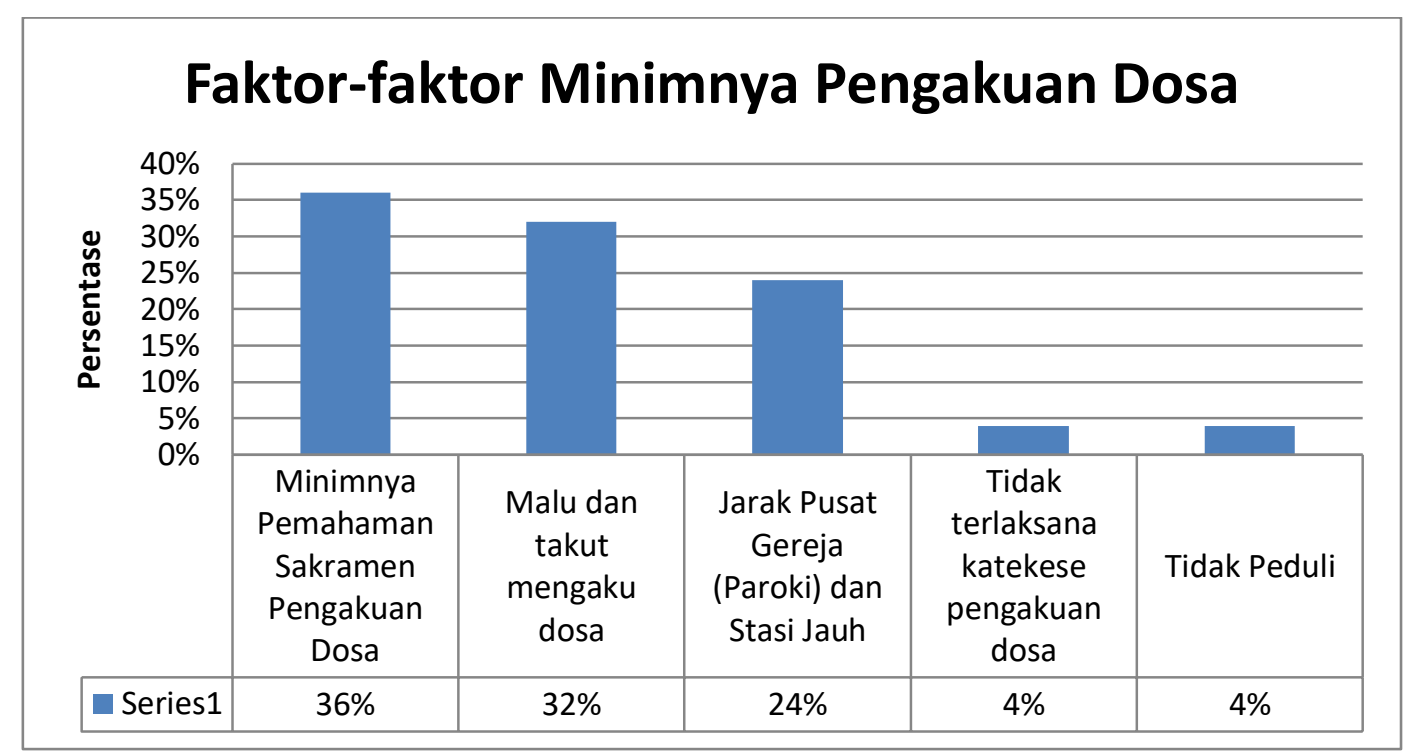

Secara umum umat Katolik memahami tata cara atau proses pengakuan dosa di ruang pengakuan. Proses pengakuan dosa diakui mudah untuk melaksanakannya. Tata cara pengakuan dosa kepada Imam antara lain, Pertama: di luar kamar pengakuan atau dalam gereja antara lain 1) Berdoa. Peniten berdoa. Contoh doa ialah "Allah Roh Kudus, tolonglah saya untuk mengingat segala perkataan, perbuatan dan kelalaian yang telah menyakiti orang lain dan yang sudah menyakiti hati Tuhan, dengan melanggar perintah-perintah-Mu. Bantulah saya untuk menyesali segala dosa saya dan dapat mengaku dengan baik, demi Kristus Tuhan dan pengantara kami, Amen. 2) Memeriksa dan menyadari serta mengingat kembali dosadosa dan menyesali dosa-dosa yang telah dilakukan. Kedua: Sakramen Tobat dalam kamar pengakuan, antara lain 1) Berlutut di hadapan Imam sambil berkata: " Bapa, berkatilah saya orang berdosa". Waktu Pastor memberkati, Peniten membuat Tanda Salib dan melanjutkan dengan perkataan: "Pengakuan saya yang terakhir adalah...., 2) Peniten melanjutkan perkataan: Dosa-dosa saya adalah.... (Peniten menyebutkan dosa). Selesai mengaku dosa peniten menyatakan: Bapa, saya menyesal atas dosa-dosa saya dan dengan hormat saya mohon ampun dan silih atas dosa-dosa saya. 3) Peniten mendengarkan perkataan Imam yang memberi nasehat dan menyampaikan penitensi direktif kepada Peniten. 4). Imam memberikan pengampunan (absolusi) kepada Peniten dengan berkata: "Allah, Bapa yang mahamurah telah mendamaikan dunia dengan diri-Nya, dalam wafat dan kebangkitan PuteraNya. Ia telah mencurahkan Roh Kudus demi pengampunan dosa. Dan berkat pelayanan Gereja, Ia melimpahkan pengampunan dan damai kepada orang yang bertobat. Maka saya melepaskan saudara dari dosa-dosa saudara, Demi nama Bapa dan Putera dan Roh Kudus". 5) Setelah selesai, Peniten mengucapkan: "Terimakasih Bapa". Peniten pulang dari ruang pengakuan dosa, berdoa dan dalam kehidupan menerapkan isi penitensi atau tindakan tobat secara nyata. 
Tindakan tobat sebagai tanda penyesalan sekaligus silih dosa dilakukan oleh Peniten. Mayoritas umat Katolik di kota Medan memiliki pengetahuan tentang penitensi yang sering disampaikan secara direktif oleh Imam kepada peniten. Tindakan penitensi atau praktik tobat yang diketahui oleh umat katolik ialah dapat dilihat dalam tabel berikut ini.

Tabel 1

Pengetahuan Umat tentang Tindakan Penitensi

\begin{tabular}{|c|c|c|}
\hline \multirow{9}{*}{ 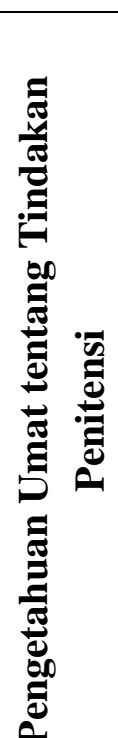 } & 1 & Doa \\
\hline & 2 & Derma \\
\hline & 3 & Karya amal \\
\hline & 4 & $\begin{array}{ll}\text { Pelayanan } & \text { terhadap } \\
\text { sesama } & \end{array}$ \\
\hline & 5 & Pantang suka rela \\
\hline & 6 & Berkurban \\
\hline & 7 & Pengampunan/Pemaafan \\
\hline & 8 & Pendamaian \\
\hline & 9 & Pertobatan \\
\hline & & \\
\hline
\end{tabular}

\section{PENERAPAN PENITENSI UMAT KATOLIK}

Penerapan penitensi yang dilakukan oleh umat katolik dapat dijelaskan berikut ini.

\section{a. Doa}

Doa adalah pengangkatan jiwa kepada Tuhan atau suatu permohonan kepada Tuhan demi hal-hal yang baik. Macam-macam doa yang telah dilakukan umat dalam kehidupan harian ialah 1) Doa pagi/malam dan doa makan. Pagi hari umat berdoa kepada Tuhan agar hari dan pekerjaan yang dilakukan diberkati Tuhan dan pada malam hari umat kembali bersyukur atas perlindungan Tuhan sepanjang hari sekaligus mohon berkat Tuhan untuk istirahat pada malam hari. Sedangkan, doa makan yang dilakukan ialah doa sebelum dan sesudah makan. Doa makan dilakukan karena ada kesadaran bahwa umat diberikan rejeki cuma-cuma oleh Tuhan melalui makanan secukupnya. 2) Doa Novena ialah doa yang dapat dilaksanakan secara pribadi atau bersama-sama selama sembilan hari berturut-turut untuk memohon rahmat khusus atau menyampaikan permohonan. Novena yang paling populer 
dilakukan oleh umat Katolik ialah novena Rosario. 3) Doa Angelus, ialah doa yang populer dan sering dilaksanakan dalam kehidupan umat Katolik secara umum dan secara khusus di wilayah kota Medan. Doa ini sering disebut juga "doa malaikat Tuhan" yang dilakukan tiga kali dalam sehari pada jam enam pagi, jam dua belas siang dan jam enam sore hari. Pengucapan doa ini sama namun maksud dan tujuannya berbeda. Pagi hari dimaksudkan untuk menghormati Tuhan, Yesus Kristus dan bersama Tuhan, umat memulai beraktivitas dalam keseharian dengan semangat kebangkitan. Pada siang hari dimaksudkan untuk menghormati sengsara Kristus saat di tengah pekerjaan yang berat, agar manusia senantiasa ingat Kristus yang telah berkorban bagi kebaikan manusia. Pada sore hari bertujuan agar manusia senantiasa menghormati Inkarnasi Allah menjadi manusia. Terlebih saat manusia hendak beristirahat, agar selalu ingat bahwa Allah selalu menyertai manusia. 4) Perayaan Ekaristi/Syukur, umat Katolik ikut serta secara aktif dalam perayaan ekaristi. Hal ini sangat beralasan karena ekaristi adalah sumber dan puncak seluruh hidup Kristiani artinya melalui komuni kudus yang diterima umat memperdalam persatuannya dengan Kristus.

\section{Gambar 4}

Penerapan Doa

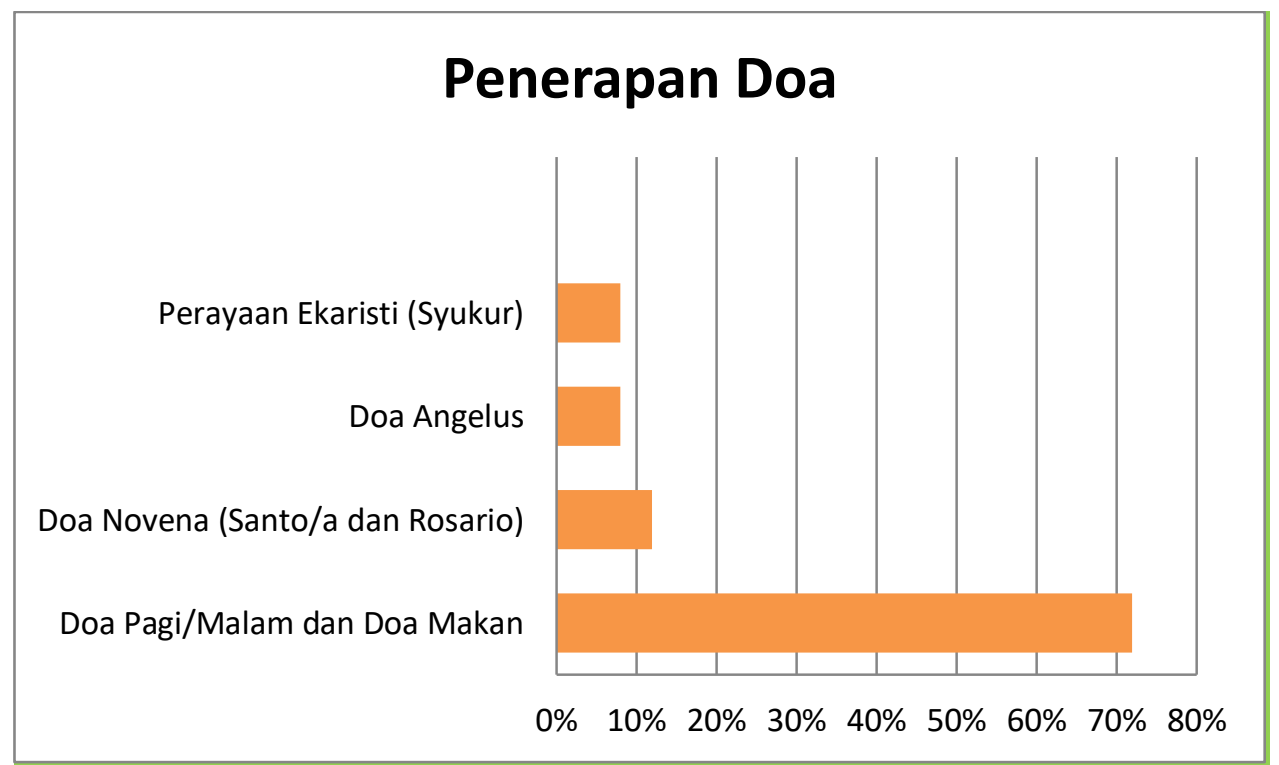

\section{b. Derma}

Tindakan penitensi sebagai lambang kasih yang nyata kepada sesama ialah berderma kepada semua orang tanpa memperhitungkan suku, agama, ras atau golongan. Secara operasional umat Katolik wilayah kota Medan memberikan derma dengan berbagai bentuk, seperti terlihat dalam tabel berikut ini. 
Tabel 2

Penerapan Derma

\begin{tabular}{|c|c|c|}
\hline \multirow{5}{*}{ 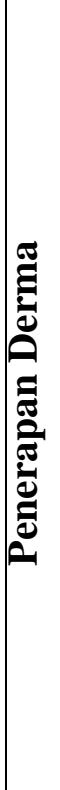 } & 1 & $\begin{array}{l}\text { Memberikan makanan dan } \\
\text { minuman kepada fakir } \\
\text { miskin }\end{array}$ \\
\hline & 2 & $\begin{array}{l}\text { Memberikan uang kepada } \\
\text { pengamen jalanan (cacat } \\
\text { tubuh) }\end{array}$ \\
\hline & 3 & $\begin{array}{l}\text { Menyumbangkan pakaian } \\
\text { ke Panti asuhan }\end{array}$ \\
\hline & 4 & $\begin{array}{l}\text { Memberikan bantuan } \\
\text { sosial (uang/barang) } \\
\text { kepada yang berduka }\end{array}$ \\
\hline & 5 & $\begin{array}{l}\text { Aksi Puasa Pembangunan } \\
\text { (APP) Masa Praspakah }\end{array}$ \\
\hline
\end{tabular}

\section{c. Karya amal dan pelayanan kepada sesama}

Umat Katolik di Medan menerapkan karya amal dengan berbagai cara dan sesuai kebutuhan orang yang ditolong. Penerapan karya amal yang dilakukan umat Katolik secara sosial yakni terlibat dalam kegiatan gotong royong di masyarakat misalnya bekerja secara bersama dengan masyarakat lain untuk membersihkan jalan atau selokan dan membersihkan sampah. Selain itu, karya amal yang dilakukan oleh umat Katolik yang bersifat humanis ialah memberikan makanan kepada orang lapar, memberikan makanan kepada anak-anak di panti asuhan, memberikan bantuan materi kepada masyarakat yang berduka dan mengunjungi orang yang lanjut usia. Kedua, umat katolik melakukan karya amal secara rohani-gerejawi yakni membersihkan lingkungan gereja, mendekorasi atau menghias gereja dengan kreatif pada saat hari raya agama dan melakukan aksi puasa dengan memberikan uang kepada orangorang miskin. 
Gambar 5

Penerapan Karya Amal dan Pelayanan

\section{Penerapan Karya Amal dan Pelayanan}

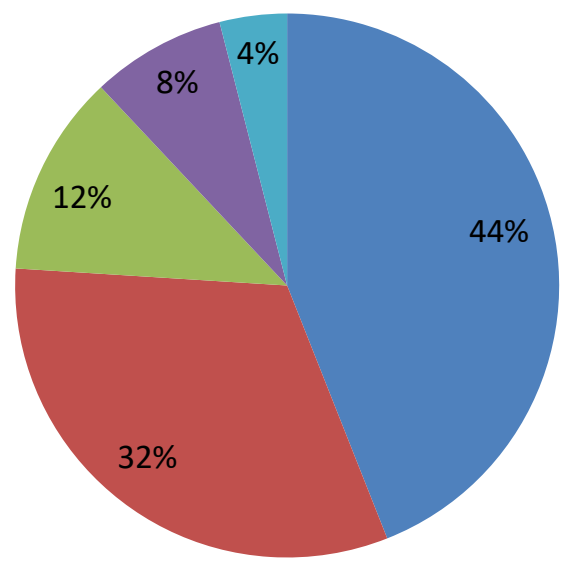

Amal dan pelayanan bagi orang lain sesuai kebutuhan dan situasi

Amal dan pelayanan di masyarakat

Amal dan pelayanan di gereja

Amal dan pelayanan dalam sikap dan tindakan

\section{d. Pantang Secara suka rela}

Umat katolik melakukan pantang secara umum pada masa Praspaskah atau sebelum masa Paskah. Umat memilih melakukan puasa yakni tidak makan daging pada masa puasa (Prapaskah) dan melakukan pantang berpakaian minim dan pantang pergaulan bebas. Dengan berpuasa dan pantang, orang menemukan diri yang sebenarnya untuk membangun pribadi yang selaras. Umat boleh memilih puasa dan pantang, namun apabila untuk kepentingan tindak tobat hendaknya umat memilih pantang yang lebih berat. Tindakan pantang yang dilakukan sama dengan tradisi yang biasa dilakukan oleh umat Katolik pada umumnya yaitu pantang atau puasa makan daging dan minum pada jam yang ditentukan. Yang wajib berpuasa adalah semua orang beriman yang berumur antara delapan belas (18) tahun sampai awal enam puluh (60) tahun. Sedangkan pantang berarti, pantang daging, pantang rokok, pantang garam, pantang gula atau manisan, pantang hiburan, dan sebagainya. Dengan kata lain umat boleh memilih pantang yang sesuai situasi dan kondisinya masing-masing. 
Gambar 6

Penerapan pantang

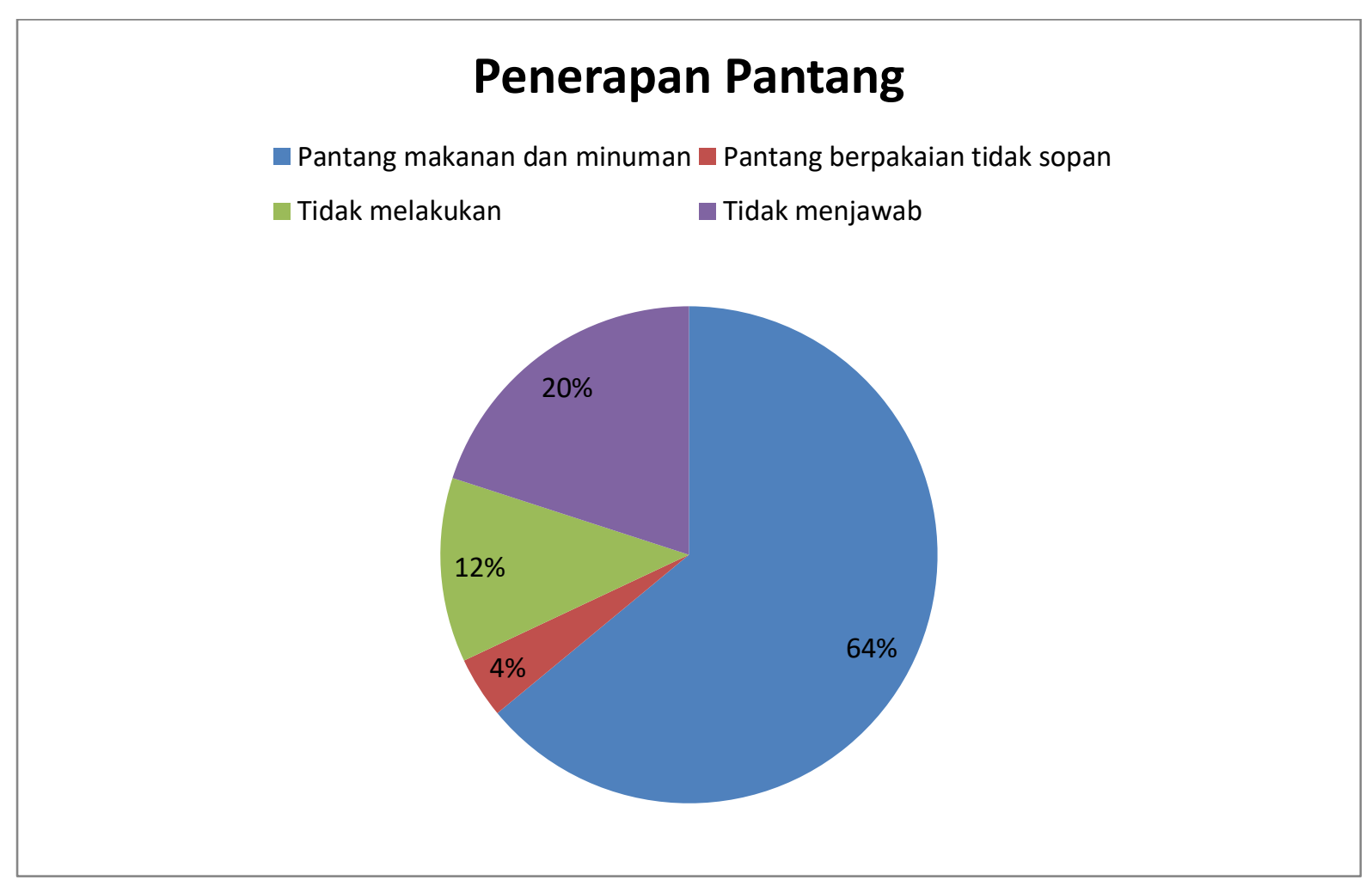

\section{e. Berkorban}

Tindakan penitensi dalam lingkup agama katolik ialah kesediaan untuk berkorban. Tindakan berkorban yang dilakukan oleh umat Katolik ialah meluangkan waktu, tenaga dan pikiran dalam mengikuti kegiatan kerohanian Gereja. Misalnya, meluangkan waktu untuk berkumpul secara rutin sekali seminggu bersama umat yang lain melaksanakan Ibadah di rumah anggota Gereja lain secara bergiliran, mengikuti latihan lagu rohani di Gereja, bersedia mengikuti doa-doa novena dalam lingkup Gereja pada hari-hari tertentu. Misalnya meluangkan waktu untuk berdoa Rosario pada bulan Mei dan Oktober, datang berdoa di rumah orang yang mengalami duka serta rela dan sedia tanpa pamrih untuk menjaga keamanan dan kebersihan lingkungan Gereja.

Penerapan berkorban dilaksanakan juga dengan cara setiap hari mengurangi takaran beras yang dimasak dari biasanya. Ini dilakukan oleh tiap-tiap keluarga yang nantinya akan diberikan kepada orang yang miskin dan lapar. Kegiatan ini dilakukan setiap masa puasa (Prapaskah) dalam agama Katolik selama satu bulan penuh. Kegiatan ini dimaknai agar solider dengan orang miskin dan lapar. Selain itu, memberikan atau menyumbangkan pakaian kepada orang-orang yang membutuhkan. 
Gambar 7

Penerapan Korban

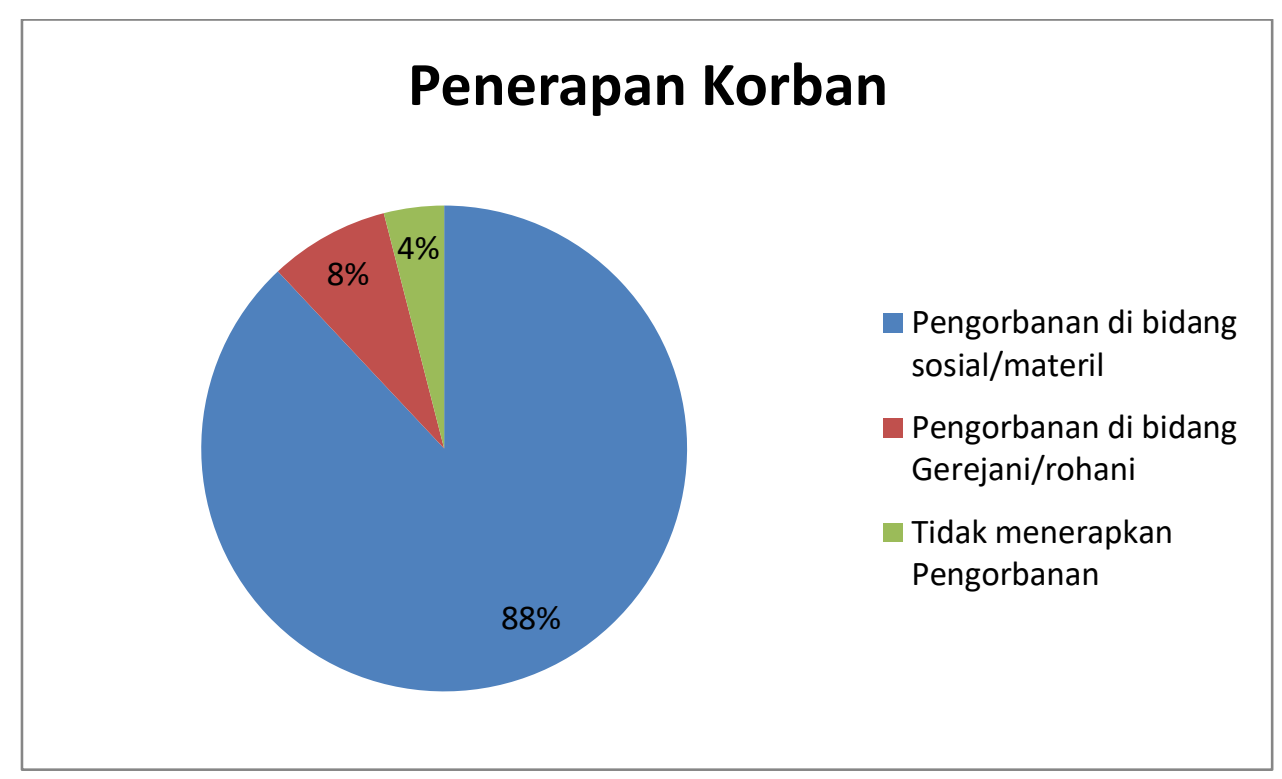

Akhirnya, dari semua informasi yang telah disampaikan, secara umum umat Katolik di wilayah kota Medan memberikan saran agar katekese atau ajaran agama Katolik tentang pelaksanaan sakramen pengakuan dosa penting disampaikan kepada umat Katolik. Pelayanan pelaksanaan sakramen inipun agar diupayakan tidak berpusat pada lingkup paroki atau pusat Gereja namun dilaksanakan juga di gereja-gereja stasi pada lingkup yang lebih kecil sehingga makna sakramen pengakuan dosa dapat dipahami. Selain itu, umat katolik mengharapkan agar pengetahuan dan pelaksanaan pengakuan dosa dalam Gereja Katolik dapat dimulai sejak dini. 


\section{Saran Umat Katolik Pada Pelaksanaan Pengakuan Dosa}

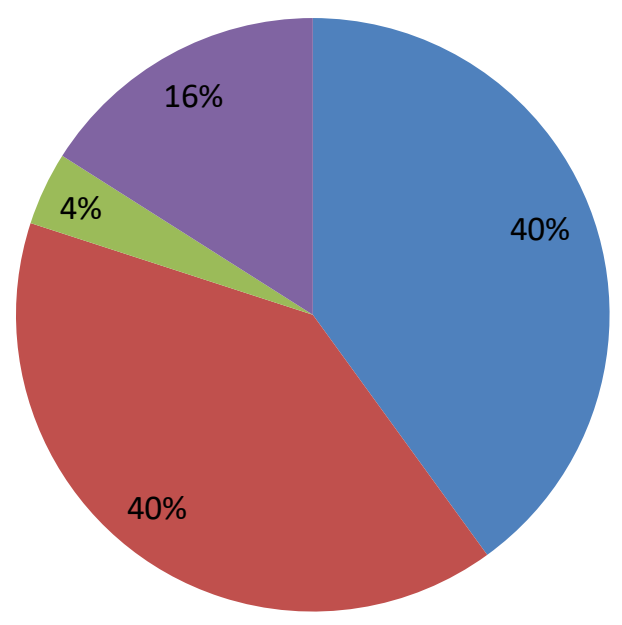

Pelaksanaan Katekese Pengakuan Dosa

- Pengakuan Dosa Terlaksana di Stasi

Pembiasaan Pengakuan Dosa sejak usia Dini

No sense

\section{SIMPULAN}

Berdasarkan hasil penelitian terdapat beberapa simpulan penelitian antara lain, Pertama: Faktor-faktor minimnya pengakuan dosa karena 1) pemahaman umat tentang sakramen pengakuan dosa sangatlah minim. Dengan kata lain, umat tidak mengakui dosanya kepada Imam karena tidak memiliki pengetahuan tentang makna dan substansi sakramen pengakuan dosa. 2) Umat menganggap bahwa dosa-dosanya tidak terjamin kerahasiaannya, khawatir jika Imam mengetahui dosa-dosanya. 3) Umat malu atau segan menyampaikan dosa-dosanya kepada Imam bahkan dirasakan menakutkan. Kedua; Berdasarkan faktor-faktor di atas para imam (conventual) di Medan, telah menyampaikan tindak tutur yang bersifat direktif kepada umat Katolik yang terdiri atas tindak tutur direktif yang bersifat meminta, mengajak, menyarankan, menyuruh, mengharapkan yang kesemuanya ini berisikan tuturan agar umat katolik berpartisipasi secara aktif untuk mengaku dosa kepada Imam agar umat memperoleh pengampunan dan keselamatan dunia dan akhirat. Ketiga; Walaupun diakui bahwa yang aktif mengaku dosa secara kuantitatif masih minim, namun bagi umat yang mengakui dosanya dan telah memperoleh pengampunan telah menerapkan penitensi (tindakan tobat) dalam kehidupan secara praktis. Penitensi yang diterapkan antara lain melakukan tindakan doa, berderma, karya amal dan pelayanan kepada sesama yang membutuhkan, pantang secara suka rela dan bersedia berkorban. Keempat: Demi peningkatan partisipan pengakuan dosa, maka baik para Imam dan umat secara keseluruhan merekomendasikan atau memberikan saran agar katekese tentang pengakuan dosa dilaksanakan dan agar pengakuan dosa dilaksanakan di semua Gereja baik pusat kota dan gereja-gereja yang ada di desa. 


\section{UCAPAN TERIMAKASIH}

Ucapan terimakasih disampaikan kepada semua pihak yang telah membantu dalam pelaksanaan penelitian dan terutama peneliti ucapkan terimakasih kepada:

1. Kementerian Riset dan Teknologi/Badan Riset Inovasi Nasional Republik Indonesia (RISTEK/BRIN RI) yang telah mengadakan program penelitian skema Penelitian Dosen Pemula (PDP) bagi kami, tenaga pendidik di Universitas Prima Indonesia, Medan.

2. Universitas Prima Indonesia melalui Lembaga Penelitian dan Pengabdian kepada Masyarakat (LPPM) telah menyediakan peluang dan memberikan arahan dan bimbingan bagi peneliti untuk melaksanakan penelitian dengan skema penelitian dosen pemula (PDP).

3. Seluruh para Imam Conventual dan umat Katolik di kota Medan, khususnya wilayah ke-5 paroki pelayanan Conventual yang telah memberikan informasi terkait pelaksanaan pengakuan dosa.

4. Semua pihak tanpa disebutkan nama satu persatu yang telah ikut membantu melancarkan dan merampungkan hasil penelitian.

\section{DAFTAR PUSTAKA}

Al. Purwa Hardi Wardoyo. 2007. Pertobatan dalam Tradisi Katolik. Yogyakarta: Kanisius.

Chaer, Abdul dan Leonie Agustina. 2010. Sosiolinguistik Perkenalan Awal. Jakarta: Rineka Cipta.

Bowo Hermaji. 2013. “Tindak Tutur Penerimaan dalam Bahasa Indonesia”. Dalam, Jurnal Cakrawala Vol 7.

Fenda Dina Puspita Sari. “Tindak Tutur Dan Fungsi Tuturan Ekspresif Dalam Acara Galau Nite Di Metro Tv: Suatu Kajian Pragmatik”. Dalam Skriptorium Vol 1, no 2.

Konferensi Waligereja Regio Nusantara. 2014. Katekismus Gereja Katolik. Ende: Nusa Indah.

Konferensi Waligereja Indonesia. 2018. Kitab Hukum Kanonik (Codex Iuris Canonici). Jakarta: Konferensi Waligereja Indonesia.

Lembaga Alkitab Indonesia. 2017. Alkitab Deuterokanonika. Jakarta: Lembaga Alkitab Indonesia.

Markus Manurung. 2014. Sudahkah Aku Mengaku Dosa ?. Medan:Bina Media Perintis.

Moleong. Lexy J. 2012. Metodelogi Penelitian Kualitatif. Bandung: Remaja Rosdakarya...

Mursia Ekawati, 2017. "Kesantunan Semu pada Tindak Tutur Ekspresif Marah dalam Bahasa Indonesia. Dalam Jurnal Adabiyyat Bahasa dan Sastra Vol. 1, No. 1. 
Rachman. 2015. “Tindak Tutur Dalam Proses Belajar-Mengajar Pada Taman Kanak-Kanak Dharma Wanita Kelurahan Wapunto Kecamatan Duruka Kabupaten Muna (Kajian Pragmatik). Dalam Jurnal Humanika, Vol 3, no 15.

Rusminto, Nurlaksana Eko. 2010. Memahami Bahasa Anak-Anak. Bandar Lampung: Universitas Lampung.

Rusminto, Nurlaksana Eko. 2015. Analisis Wacana Sebuah Kajian Teoritis dan Praktis. Yogyakarta: Graha Ilmu.

Silvester Adi Prasetyo. 2018. Analisis Tindak Tutur Direktif pada Interaksi Guru dan Siswa dalam Pembelajaran Di Kelas V SD Kanisius Sumber Magelang Tahun Ajaran 2017/2018. Skripsi.

Yuliarti, Rustono, Agus Nuryatin. 2015. Tindak Tutur Direktif dalam Novel Trilogi Karya Agustinus Wibowo. Dalam Jurna Seloka: Jurnal Pendidikan Bahasa dan Sastra Indonesia, Vol 4 (2) 